\title{
ESTA NOTA ES BIEN BACÁN
}

\section{THIS NOTE IS WELL BACAN}

Carlos Gamero Esparza: Universidad Inca Garcilaso de la Vega (Perú). carlos.gamero@ozu.es

\section{CURRÍCULUM VITAE}

Reconocido Periodista peruano del Diario OJO de Lima. Licenciado con Diploma de Honor en la Universidad Inca Garcilaso de la Vega.

\section{RESUMEN}

La jerga es un reclamo de identidad de un grupo de hablantes respecto a un universo mayor. Las lenguas especiales resultan de la segmentación social; por su principio son, pues, tan naturales como los dialectos, pero nacen siempre del fondo de una lengua común, de la cual ordinariamente continúan alimentándose. Eso ocurre, por ejemplo, con el español de Perú. Sus giros verbales, palabras y frases se han convertido en un sello de identidad propio. Los especialistas lo llaman lengua especial utilizada por diferentes grupos sociales en distintas circunstancias. En Perú se conoce como argot criollo.

\section{PALABRAS CLAVE}

Jerga - Identidad - Criollo - Hablantes 


\begin{abstract}
Slang is a claim of identity of a group of speakers with respect to a larger universe. The languages are special social segmentation, for its principle, then, are as natural as the dialects, but the bottom are always born of a common language, which continue to feed normally. This happens, for example, Spanish in Peru. His turns of phrase, words and phrases have become a hallmark of its own. Specialists call this special language used by different social groups in different circumstances. In Peru, it's known as Creole slang.
\end{abstract}

\title{
KEY WORDS
}

Slang - Identity - Creole - Speakers

\section{ÍNDICE}

1. Introducción

2. Tropos. Metáforas y voces prestadas

2.1. Pa' todos los gustos...

3. América "Ladina"

4. Voces y expresiones las de mi tierra...

5. ¿Química lingüística?

5.1. La replana criolla, una subcultura del argot

6. Los recursos ingeniosos del argot criollo

7. ¿Sabía Usted que...?

8. Para saber más

9. Notas

10. Procedencia de las imágenes

11. Recortes: La Divina Jeringa 


\section{TEXTO:}

\section{Introducción}

Estos giros verbales, palabras y frases de cajón, de incontrastable ingenio, se han convertido en el sello de identidad propia para pueblos como el peruano. Se trata de una "vox populi" que discurre en la vida cotidiana y forma parte del acervo cultural, sin que nadie le ponga reparos ante tanta "trasgresión" lingüística o gramatical; es más, hasta los académicos de la lengua lo toman como algo normal... Ellos también hablan en jerga, muy a despecho de la forma y el fondo; al empleo de la jerga o argot no se escapa nadie. Son voces, palabras, frases, de la calle y de la casa y de la escuela y de la universidad y de los gremios profesionales y de los sindicatos y de todo el mundo... Aquí hasta el Presidente de la República se "cholea", como se diría, pues el Perú es una mixtura cultural variopinta de todas las sangres. Por ello, que no extrañe al lector si aquí lee cosas que para un peruano son tan corrientes.., como también tan extrañas, pero comunes en otros países de su mismísima Latinoamérica... Así podemos escuchar cosas como: "una tecla millonaria se enfrió", "aquella ñolora jala con pitucos", "te jalo pa'tu casa", "la "guagua" llorona se durmió", "a ese arquero se le metió la redonda por la guacha".

Los especialistas llaman a esta peculiar "fabla", "jerga" o "argot": una lengua especial utilizada por diferentes grupos sociales en distintas circunstancias. En Perú se llamaría "argot criollo" o "jerga criolla" a esta variedad de términos de diversas procedencias que se han fusionado o combinado para crear otro lenguaje "paralelo" muy peculiar y propio de estas tierras, producto de una sabiduría popular inigualable. 


\section{Tropos. Metáforas y voces prestadas}

El bueno de don Pedro Paz Soldán, cuyo pseudónimo literario era Juan de Arona $\left(1839\right.$ - 1895) ${ }^{1}$ (Nota 1), uno de los primeros estudiosos de la jerga en el Perú, creyó confundir jerigonza con la mismísima fabla de sus paisanos, aunque en cierto modo lo parecía, una cosa con la otra (jerga y jerigonza), debido a lo que escuchaba desde muy niño de su familia, de las empleadas que servían en su casa limeña, de las visitas que recibían sus padres, de los tenderos de avituallas, de las vivanderas en el mercado, de los traviesos mozalbetes en el parque, del habla apresurada de los conductores de coches, del grito de los vendedores de golosinas; todo semejaba un confuso laberinto sin sentido, donde una palabra podía parecer otra, o una frase podría tener más de un significado, cada cual con su propia historia (o jerga); empero, inteligente él, supo entender que ese lenguaje no era un idioma extraño, no era, pues, un habla necesariamente de incultos -ya que se lo escuchó hasta a su padre, un prominente personaje de su época -; no se trataba, entonces, de un decir sólo de negros, de cholos o de indios..., sino que conformaba un entramado de palabras, frases, oraciones, todas tomadas, más que del español que le habían enseñado en la escuela, de la mismísima calle, de la vida cotidiana, de ese mundo de colores, aromas y sabores llamado Perú que recién, hacía pocos decenios, había despertado a la vida republicana, como heredero de un pasado glorioso.

Así, pues, la jerga criolla se le presentó como ese insólito universo y Paz Soldán comenzó a estudiar lo que acabó llamando "peruanismos". La lingüística es una ciencia que se encarga de estudiar el idioma, la lengua que uno habla, la misma lengua de la vida de cualquier hijo de vecino, pero esta misma ciencia estaba en pañales en el Perú del siglo XIX. Más aún así, sin preocuparse por si la lingüística estaba en París o en Madrid, el poeta, metido a lingüista de postín, se empeñó en

\footnotetext{
1 "Biblioteca Peruana". Promoción Editorial Inca SA (PEISA) Lima, 1974.
} 
romper esa barrera de indiferencia que existía en los círculos literarios en torno al habla del vulgo. Y se sumergió en aquel mundo que nadie se había atrevido a tocar, el habla del Perú profundo.

Desde aquella época, gracias al trabajo de este notable lingüista, la jerga criolla comenzó a ser tomada en serio, y pronto más de un autor se preocupó por profundizar en sus infinitos laberintos fonéticos: nuestro español "paralelo" empezó a revelar sus insospechados secretos. Y ésta es la razón, o las razones por las cuales decimos "que tal floro, pues".

Una de las formas ingeniosas del argot criollo peruano es el tropo, esto es, "dar vuelta a una cosa", también cambiar el significado para darle más énfasis, por ejemplo, se dice: "Demetrio es una rata". Aquí la palabra "rata" sería sinónimo de sinvergüenza. Otra de las formas lingüísticas creadas por la fabla peruana es aquella que emplea metáforas, es decir, el cambio de un significado por otro. Aquí la inventiva popular no tiene desperdicio. Así escuchamos con frecuencia: "tus ojazos son dos luceros que iluminan mi camino", "quítese la cumbre (sombrero) pa' chamullar al jefe", "la redonda (pelota) fue expulsada del campo", entre otros. 


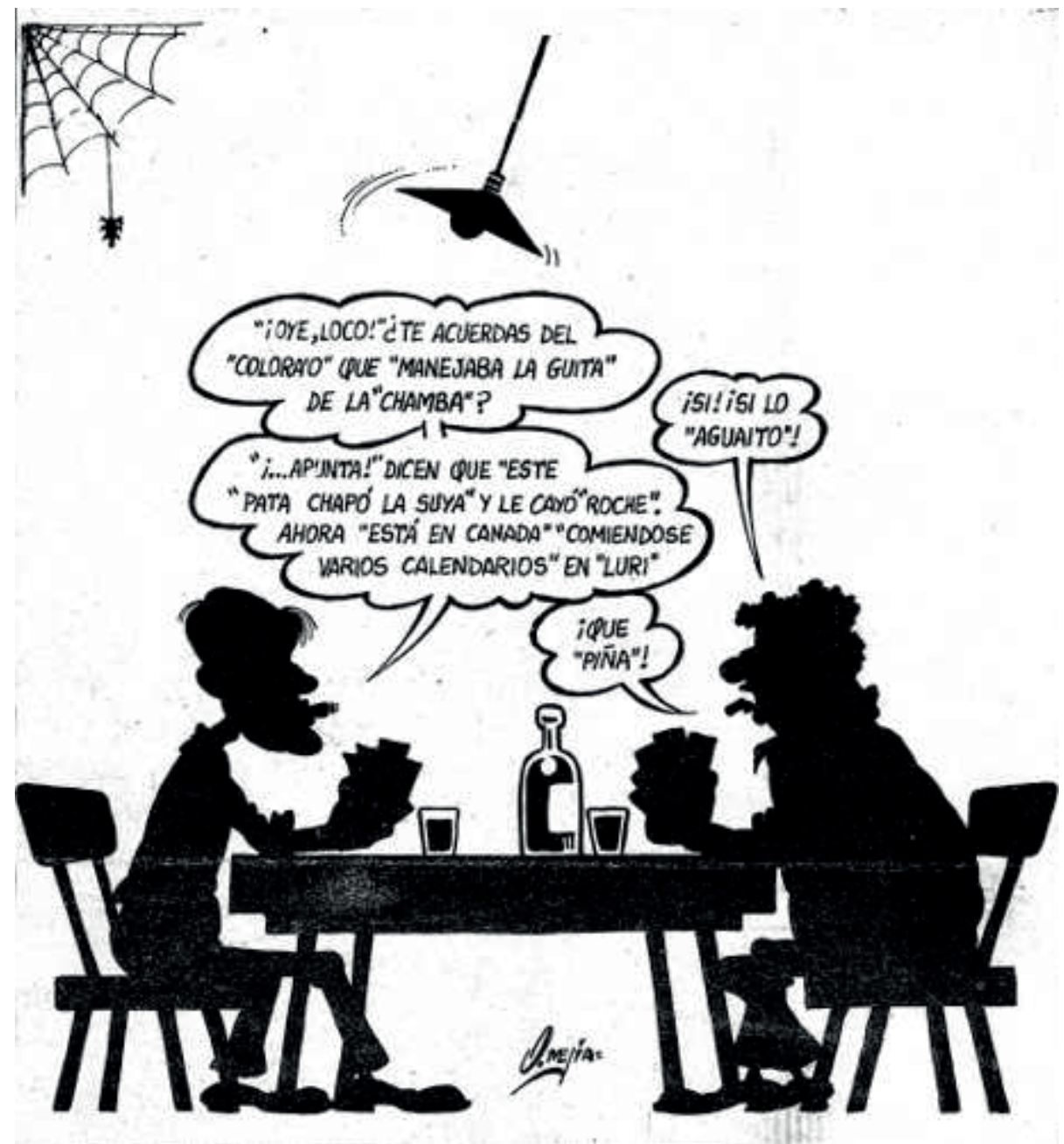

Figura 1. "Amigos conversando". Caricatura de Oswaldo Mejía.

Suplemento Dominical del Diario OJO, Lima (1990).

El vocablo dinero es un concepto que ha desarrollado diversas equivalencias. Así, durante la época de la hiperinflación en el Perú (1989-1992), cuando reinaba el devaluado "Inti" por símbolo monetario, se solía decir: "este libro me costó diez palos". Desde luego que en cursi no se trata de palazo limpió, sino de diez millones de intis, monto que ahora se traduciría por diez mil nuevos soles, nuestra actual moneda. Ahora se entiende por "palo" a un millón de nuevos soles (unos 300.000 dólares) Muy comunes son también frases como "sin moscas (plata) no puedo ir al estadio", "le robaron la grati" (la bonificación especial que se suele dar en julio a los trabajadores), "con Guillermina (coima) se arregla todo". 


\subsection{Pa' todos los gustos...}

Hay voces que han sido "tomadas en préstamo" de otros idiomas extranjeros. Es muy común ver palabras u oraciones francesas e inglesas adaptadas al léxico popular. Por ejemplo se dice "smoking" (chaqueta de etiqueta), "baby doll" (ropa de dormir), "brassiere" (el cierre relámpago del pantalón), "hot dog" (perro caliente, un popular sándwich alargado con salchichas aderezadas con mostaza, salsa de tomate y mayonesa).

Estas voces, llamadas también "extranjerismos", son una muestra de la permeabilidad, de la variabilidad lingüística, del habla popular de nuestro país -que también se aprecia en el resto de Latinoamérica-. Las voces foráneas han contribuido a darle más animación a esta lengua particular. Así, es común escuchar cosas como: "es la hora del lonche" o "los gringos botan la plata como si nada". Son, pues, términos que utilizan voces foráneas, del inglés en este caso, ya que "lonche", que en el Perú equivale a cena o comida de la tarde, viene del anglosajón "launch", almuerzo; mientras que "gringos" es una voz compuesta, algo despectiva (de la frase "green go home" (Nota 2): verdes, váyanse a casa), con la que se señala a los norteamericanos. No hay que olvidar, por otro lado, que "gringo" es, en nuestro medio, un término de claro tinte elitista, incluso racista, pues, siendo sinónimo de "rubio" o "blanquiñoso" (de raza blanca o piel clara), hace referencia a una categoría social -de individuos bien peruanos, por cierto- que, aunque minoritaria, suele discriminar a la mayoría "chola" (mestiza) o indígena, que representa las tres cuartas partes y algo más de la población peruana.

Como éstas, muchas denominaciones foráneas se han asimilado a nuestro acervo lingüístico, "castellanizándose", por así decirlo, de modo que no es raro escuchar cosas como: "mañana luquearemos esa peli" (derivado de "to lock", mirar, espectar), "los chuzos importados suben de precio" (de "shoes", zapatos), "para todo se necesita 
monis" (de "money", dinero). También hay autoctonismos que vienen de voces quechuas o yungas (este último un dialecto de los Andes centrales y del sur peruano), así se oye por ahí: "la guagua llorona está durmiendo" (de "wawa", bebito), "unos joros corrían detrás de la camioneta" (de "coro", niño, muchacho)

También el argot criollo suele recrear formas tradicionales, dando lugar a nuevas voces producto de la inagotable imaginaria popular. Para esto se utiliza una gran variedad de frases onomatopéyicas: "no nos sobra chinchín (dinero) para regalar", "por gambusinero se comerá un cañazo" (ladrón en la cárcel), "no me vengan con trafa" (trampa), "el premier (primer ministro) soltó el paquetazo" (medidas económicas).

Las variedades del argot son interminables. En su diccionario "Argot Limeño o Jerga Criolla del Perú", el estudioso Guillermo E. Bendezú Neyra² hizo una sabrosa recopilación de términos castizos. Hay para todos los gustos, he aquí algunos: "Budín", pésimo, ej.: "el partido entre Alianza y la "U" estuvo budín"; "hacer chacra", burlarse o hacer chirigota, ej.: "...no me hagas chacra porque te sueno de caliente", o lo que es lo mismo, te zurro a golpes por burlarte de mí; "jamón", persona muy madura, ej.: "tu prima ya es jamona"; "por lo menos llega a 45 abriles, aunque la bandida está bien conservada a pura droga", por decir que vive de fármacos; "chutear", patear o dar de puntapiés, ej.: "...déjame chutear esta bola"; "la mamadera, las arcas fiscales de un gobierno burocrático, ej.: "los golpistas acabaron con toda esta mamadera"; "maní to'ta'o, chino o asiático, ej.: "un manitotao no quiso darme vuelto porque compré puchos (cigarrillos) nacionales"; "misio", el que tiene los bolsillos vacíos, ej.: "...ipero estoy misio compadre!"; "misti", persona de raza blanca, ej.:"no quiero ningún misti a mi lado, me gustan los chancacas" (morenos); "mocho", calzoncillo, también sinónimo de dañado o accidentado, ej.: "... para este verano

${ }^{2}$ Mencionado por Bendezú en "Argot Limeño o Jerga Criolla del Perú". Editora e Importadora Lima. Lima, 1977. 
necesito unos mochos rareza". Esta última voz también sirve como sinónimo de cortar, reducir, disminuir, ej.: "le mocharon el sobre", o lo que es lo mismo, "le recortaron el sueldo".

$\underline{\text { Lo que dice el Diccionario de la Real Academia Española. }}$

argot. (Del fr. argot)

1. m. Jerga, jerigonza.

2. m. Lenguaje especial entre personas de un mismo oficio o actividad.

jerga2. (Der. regres., seguramente a travs del prov., del fr. jargon, y este onomat.).

1. f. Lenguaje especial y familiar que usan entre sí los individuos de ciertas profesiones y oficios, como los toreros, los estudiantes, etc.

jerigonza. (Del prov. gergons).

1. f. Lenguaje especial de algunos gremios.

2. f. Lenguaje de mal gusto, complicado y difícil de entender.

3. f. coloq. p. us. Acción extraña y ridícula.

\section{América "Ladina"}

No en vano este título. América es ladina porque su gente ha tenido la audacia de la iniciativa, cambiando su lengua castiza por otra que se acomoda a su mundo y a su cotidianeidad. Y así, cada país, cada ciudad, cada gente, es ladino, porque ha creado su fabla íntima con su innata creatividad. Desde la llegada de los españoles al nuevo mundo, esta lengua especial adoptó sus propios modismos, que cambian de país en país, hasta el punto de que una palabra o frase propia de un lugar, puede significar algo totalmente diferente en otro, a pesar de hablar la misma lengua. Palabras, voces y diálogos son el reflejo de ese ingenio criollo en cada rincón de las américas -pues la 
palabra "criollo" no es patrimonio del Perú, hay criollos panameños, venezolanos, puertorriqueños o mexicanos-, a veces no exento de agudeza, gracia y cundería, y con su buena dosis de irónico sarcasmo; y esto es algo que en este mundo globalizado por el Internet conviene conocer y dominar para evitar malos entendidos, o situaciones embarazosas -recomendación nada ociosa, sobre todo para quienes utilicen el correo electrónico con frecuencia o decidan viajar a estos países, no vaya a ser que por decir algo confianzudamente, se cometa una torpeza y...-, o para conocer un poco más de las costumbres de los barrios de Hispanoamérica.

"Oye, pana, ese tipo es una argolla".

Parece una frase inofensiva. Aquí, en cualquiera de nuestras esquinas, podría sonar a algo así como: "ese pata es un argollero", pero no es así. Si se encuentra en Venezuela y alguien le hace ese comentario, pues simplemente le está diciendo que a quien señala es a uno de nuestros "invertidos" $u$ hombres afeminados; pero no se preocupe más de la cuenta, porque "pana" también es el amigo, el "pata", el "choche", con el que se toman unas "chelas" (cervezas) o se ponen a piropear a las "jermas" (mujeres guapas) en una tarde de bochorno.

"En la playa hay varios bichis".

Si va para México en época playera, no se extrañe de escuchar esta frase tan castiza del país de los cuates. Pero no se refieren a los bichitos que acompañan a los bañistas, sino a los "snobs" puertorriqueños... o nuestros conocidos nudistas, calatos, que pululan por las playas en traje de Adán.

"¡Chita la payasa, estoy rajado!" 
Propia de Chile, esta tremenda expresión no es novedad para un peruano. Pero ¿saben realmente su significado? Pues lo mismo que cuando cualquier estudiante puertorriqueño dice que está "colgado", otro español dice que está "suspendido" o, aquí, en Lima, uno de nuestros muchachos revela la desdicha de estar "jalado", no ha aprobado en un examen. $\mathrm{Y}$ es que andamos por predios estudiantiles, donde todo el mundo sabe lo que es un "plaje". Pero si se profiere tal mensaje en la Madre Patria, esto ya es otro cantar, pues en la tierra del Ingenioso Hidalgo es una píldora, mientras que en México es una denominación de acordeón.

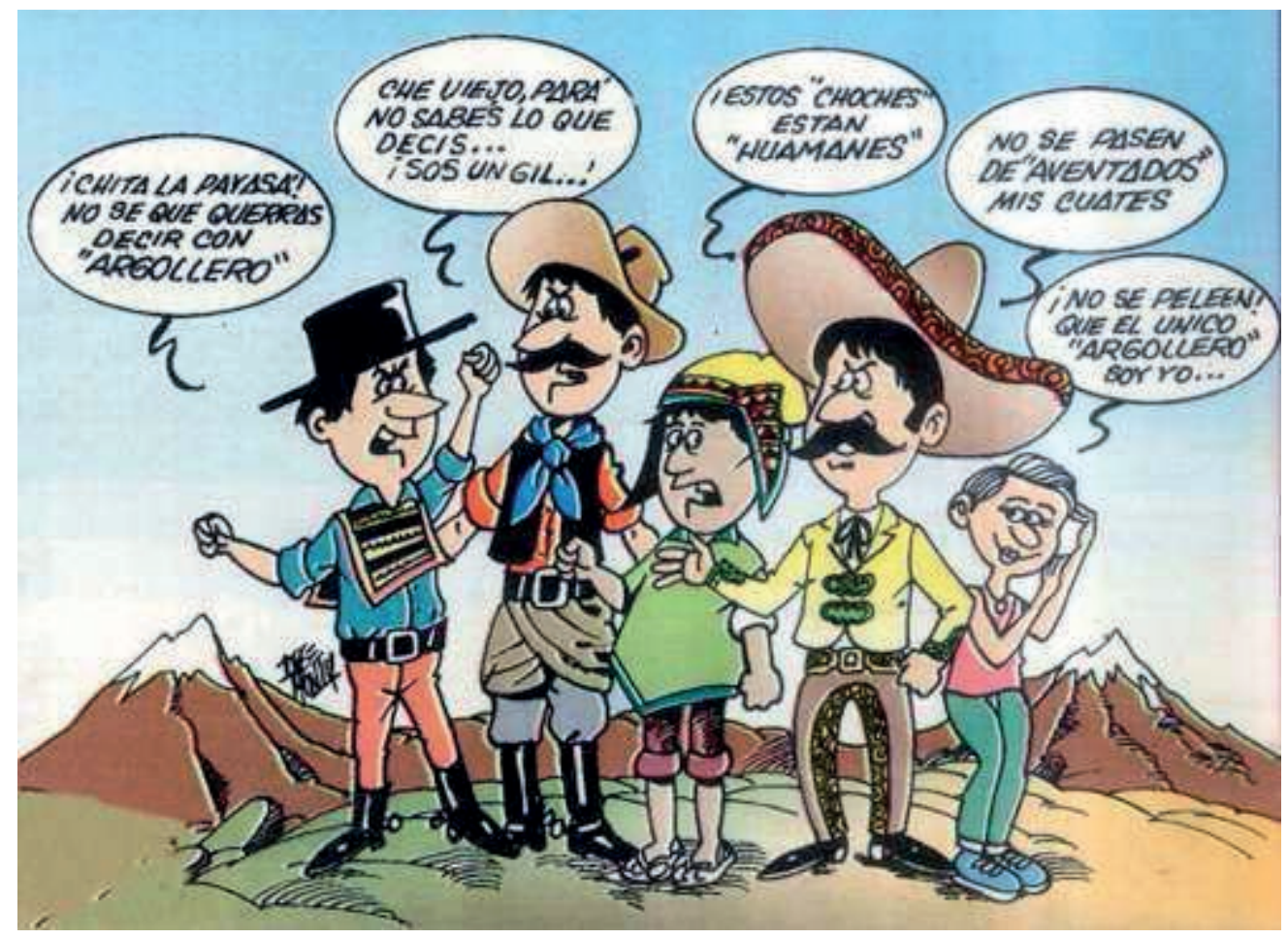

Figura 2. "No soy un argollero". Caricatura de Jorge Monterrey.

Suplemento Dominical del Diario OJO, Lima (1998).

"¡Cuidado!, don Anselmo es de grado dos".

Tipejos como éste abundan tanto en Chile como en nuestro deprimido suelo peruviano. ¡Claro!, y muy probablemente uno de esos "grado dos" ya haya pasado 
frente a nuestras narices... o ya debe haberlo puesto en lista de espera. ¿Entendió? Este apelativo le queda muy bien, por cierto, a nuestros famosos "cabeceadores" -no, los futbolistas no-, esa singular especie que anda criando culebras por todas partes, es decir, deudas, "arrugas", como decimos en el Perú, aunque no pueden ni podrán con los inspectores de Hacienda ¿o sí?

"Eres un pendejo, vale".

En Venezuela, país tan machista como el nuestro, si a un varón lo tratan de "pendejo", realmente puede considerarlo un insulto y muy denigrante. Esta palabreja, sin embargo, es más bien de tono despectivo en el Perú, donde significa "hombre mantenido por una mujer", sobre todo si es joven. ¿Cómo respondería un peruano ante semejante improperio? Bueno, los venezolanos se sorprenderían que no lance ningún puñetazo y que más bien infle el pecho.

"Oye, huevón, vamos al cine".

Ante esta expresión nada amable, un peruano respondería con otra lindeza igual o peor que semejante improperio. Pero nuestros amigos chilenos se sienten muy cómodos con esta frase, no les afecta que se la digan, a pesar de que una de sus interpretaciones es "estúpido", entre amigos asume un significado más cariñoso. Mientras tanto, en los llanos venezolanos, encontramos una de sus más expresivas variantes, "ahuevonado", que ingresa en un terreno menos lesivo aún, pues señala a una persona atontada, aletargada, desganada, perezosa, es decir...

"Ahí va ese achantado de Felipe".

Válida en la tierra del joropo y en los predios costarricenses, esta expresión se refiere a esa otra especie humana que por aquí, en el Perú, denominamos nada menos que 
"flojos". Claro, esos perezosos y haraganes que colman las esperanzas de cualquiera, como los benditos "enchufados" que son el colmo del oportunismo. Sí, a eso vamos, a los "enchufados", como los conocen en tierras ibéricas, pues ésos son los muy populares, pero nada simpáticos, "envarados" de la burocracia dorada.

"Oye, mira esa bailarina... ella es un avión".

Si en el Perú escucha una frase como ésta, puede creer que están elogiando las habilidades que alguna amiga muy querida tiene para la danza. Pero si está en Colombia, quien dijo eso recibirá una buena y sonora bofetada. Sí, en la tierra colindante, Venezuela, llaman así a las "cueros", chicas que tienen por costumbre hacerse la vida más fácil y sencilla que el resto de las mujeres, y que por estos lugares tienen por hábito aguardar silenciosamente en las esquinas o sentarse cómodamente en bares nocturnos. ¡Ajá! Son las "arañas" mexicanas, nuestras conocidas "rucas", mujeres de la noche. Figura 2. "No soy un argollero". Caricatura de Jorge Monterrey. Suplemento Dominical del Diario OJO, Lima (1998).

"¡Cuidado!, don Anselmo es de grado dos".

Tipejos como éste abundan tanto en Chile como en nuestro deprimido suelo peruviano. ¡Claro!, y muy probablemente uno de esos "grado dos" ya haya pasado frente a nuestras narices... o ya debe haberlo puesto en lista de espera. ¿Entendió? Este apelativo le queda muy bien, por cierto, a nuestros famosos "cabeceadores" -no, los futbolistas no-, esa singular especie que anda criando culebras por todas partes, es decir, deudas, "arrugas", como decimos en el Perú, aunque no pueden ni podrán con los inspectores de Hacienda ¿o sí?

"Eres un pendejo, vale". 
En Venezuela, país tan machista como el nuestro, si a un varón lo tratan de "pendejo", realmente puede considerarlo un insulto y muy denigrante. Esta palabreja, sin embargo, es más bien de tono despectivo en el Perú, donde significa "hombre mantenido por una mujer", sobre todo si es joven. ¿Cómo respondería un peruano ante semejante improperio? Bueno, los venezolanos se sorprenderían que no lance ningún puñetazo y que más bien infle el pecho.

"Oye, huevón, vamos al cine".

Ante esta expresión nada amable, un peruano respondería con otra lindeza igual o peor que semejante improperio. Pero nuestros amigos chilenos se sienten muy cómodos con esta frase, no les afecta que se la digan, a pesar de que una de sus interpretaciones es "estúpido", entre amigos asume un significado más cariñoso. Mientras tanto, en los llanos venezolanos, encontramos una de sus más expresivas variantes, "ahuevonado", que ingresa en un terreno menos lesivo aún, pues señala a una persona atontada, aletargada, desganada, perezosa, es decir...

"Ahí va ese achantado de Felipe".

Válida en la tierra del joropo y en los predios costarricenses, esta expresión se refiere a esa otra especie humana que por aquí, en el Perú, denominamos nada menos que "flojos". Claro, esos perezosos y haraganes que colman las esperanzas de cualquiera, como los benditos "enchufados" que son el colmo del oportunismo. Sí, a eso vamos, a los "enchufados", como los conocen en tierras ibéricas, pues ésos son los muy populares, pero nada simpáticos, "envarados" de la burocracia dorada.

"Oye, mira esa bailarina... ella es un avión". 
Si en el Perú escucha una frase como ésta, puede creer que están elogiando las habilidades que alguna amiga muy querida tiene para la danza. Pero si está en Colombia, quien dijo eso recibirá una buena y sonora bofetada. Sí, en la tierra colindante, Venezuela, llaman así a las "cueros", chicas que tienen por costumbre hacerse la vida más fácil y sencilla que el resto de las mujeres, y que por estos lugares tienen por hábito aguardar silenciosamente en las esquinas o sentarse cómodamente en bares nocturnos. ¡Ajá! Son las "arañas" mexicanas, nuestras conocidas "rucas", mujeres de la noche.

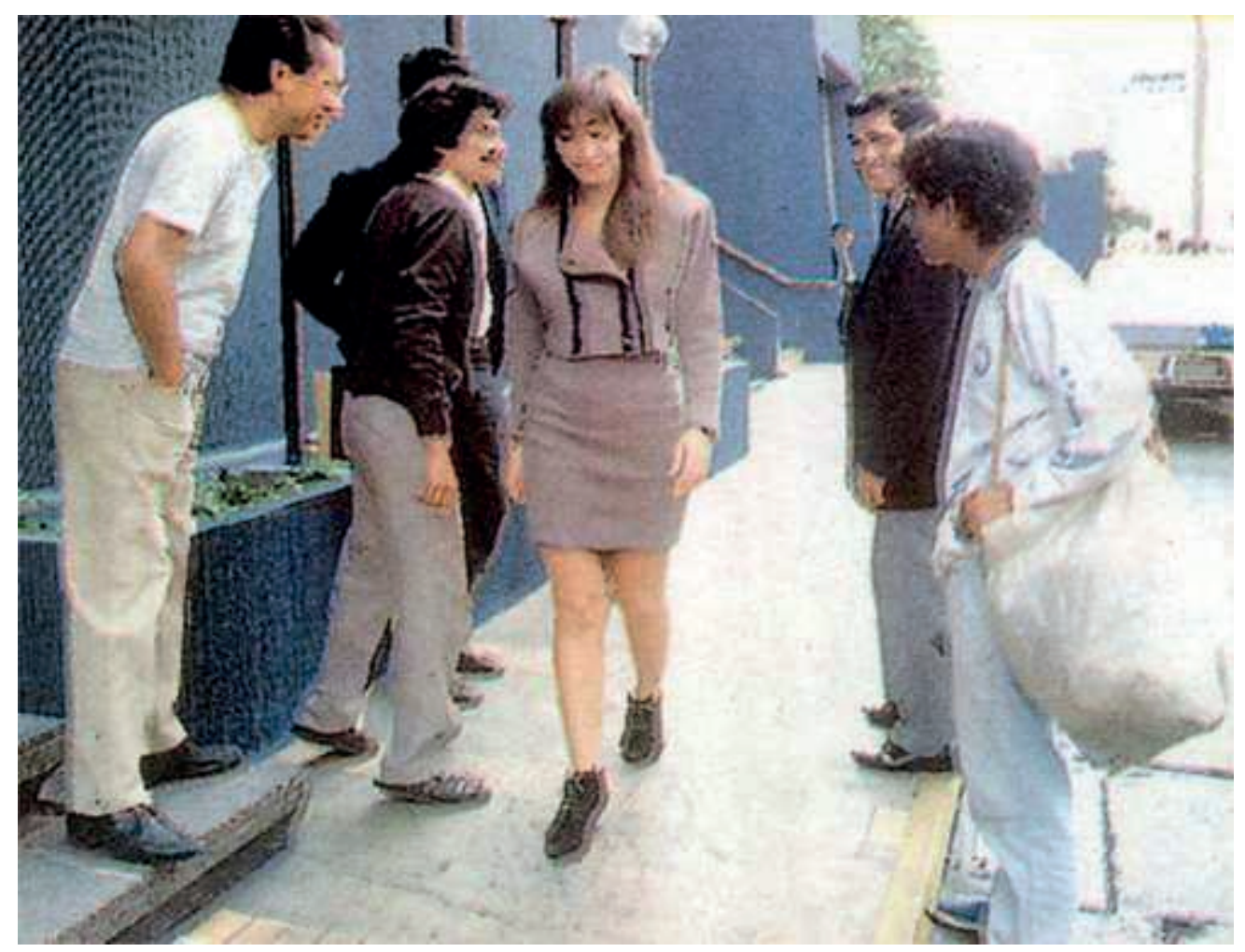

Figura 3. Hay que tener cuidado con los piropos. En Colombia, jamás diga a una chica que es un "avión". Foto archivo OJO (1998).

\section{Voces y expresiones las de mi tierra...}

Éstos son términos muy representativos, que señalan situaciones o emociones o estereotipos. 
"Jaime o Jaimita".

Ésta es para los dominicanos nuestra graciosa "garúa", aquella fina llovizna, tan típica de la costa peruana, que encanta por su suavidad, mientras el tristemente célebre fenómeno de El Niño no llega ni por asomo a nuestras playas, es decir, ni siquiera un chorro de agua.

Y los uruguayos saben a la perfección que los "chorros" pueden ser corrientes de agua, pero también algo muy peligroso para sus billeteras, por eso se cuidan de los "chorros", nuestros conocidos "choros", los amigos de lo ajeno que pululan por las calles de cualquier ciudad peruana, en busca de algún desprevenido.

"¡Aloha! ¡Aloha!"

No, no se trata de Hawai, ni que ocho cuartos. Así es como se saludan en Chile, en vez de ¡hola! Y ahí mismo, nuestros amigos sureños describen la infidelidad de una manera especial: "ella me ha gorreado", se dice, entonces, situación que nosotros asumimos más bien como un abuso de confianza, como en todas esas circunstancias cuando el mismo fulano coge tus cigarrillos, o pica un sencillo cada día porque le falta para el pasaje, o no deja tranquila a la familia siempre con la mano estirada. Es decir, el sinónimo de la "frescura", de la "conchudez" - valga la ordinariez-, como decimos por este valle de lágrimas.

"La combi loca abolló una tombita".

En su diccionario de "Argot Limeño o Jerga Criolla del Perú ", Guillermo Bendezú cuenta que, en el Perú, se aplica el término "tombo" a los policías, debido a los grandes botones de sus uniformes verdes. Esta palabra se volvió con el tiempo una acepción popular que después fue utilizada por la llamada "prensa chicha", el 
periodismo amarillo, que bautizó como "tombitas" a las mujeres policías que ahora se encargan de dirigir el tráfico en las congestionadas calles limeñas. Es así que se acuñó esta frase, derivada de "combi", esas pequeñas camionetas, convertidas en vehículos de transporte urbano de pasajeros, famosas en nuestro medio por la irresponsabilidad de sus conductores, y de "abollar", sinónimo de atropellar, golpear, chocar, estrellarse. Ya se imaginará, pues, el lector, las circunstancias que aquí describimos, con esta frase de arriba; se trata de un hecho frecuente en nuestras calles, de reiterada cobertura mediática.

"No digas 'coger' en Buenos Aires".

Acá, en cualquier ciudad peruana, nosotros podemos coger cualquier cosa. Podemos coger el autobús, el cenicero, el taxi, el lapicero, una botella y hasta una buena amiga. Pero si está de paso por la irritable Argentina, mejor -en principio- no se lo diga a la primera chica que vea y desee entablar amistad con ella. $Y$ es que entre los paisanos de Gardel "coger" tiene el mismo trasfondo de nuestro popular "chancay" o "chacachaca" (acto sexual). Ahora bien, si se ríen de usted cuando dice que va a coger el autobús o lo manden a los cuatro infiernos cuando le susurre eso a su amiguita, no diga que no se lo advertimos.

"¿Esto es una vaina!"

Si por esas casualidades de la vida, conoce a algún venezolano de buenas maneras, mejor trate de evitar pronunciar esta frase cuando se suscite algún problema o dificultad. De no ser así, su acompañante lo mirará tres veces, y por todos los ángulos, para tratar de averiguar donde está la "vaina". Y es que en su país tiene el mismo significado que en Argentina tiene "busete", otra palabreja que busca de manera solapada referirse a la mayor de las intimidades físicas femeninas... 
"...ni de a vainas".

Mientras para los paisanos del libertador Simón Bolívar y los de Gardel, el término "vaina" tiene hartas connotaciones sexistas, en Perú y Ecuador -sobre todo en el primero de estos países - esta palabra se suele utilizar como sinónimo de "nada de tonterías" o bien, "ni en broma". Así, por ejemplo, durante muchos años, en las épocas en que el conflicto fronterizo entre Perú y Ecuador estaba en toda su ebullición, el mismo que generó varios enfrentamientos armados, en el norte peruano se solía decir: "ni Tumbes, ni Jaén, ni Maynas, ni de a vainas", en rechazo a la vieja pretensión ecuatoriana de anexionarse estas tres provincias peruanas.

"Pa' su macho".

Otra frase bien peruana, que también es utilizada en Ecuador y parte de Bolivia. Esta frase suele acompañar alguna expresión aseverativa o sentencia inapelable, o algún hecho que puede generar sorpresa. Por ejemplo, parafraseando a Bendezú, se suele decir por estos predios cosas como "pa' su macho, ninguno de nosotros ha salido aprobado".

"Esta nota es bien bacán".

La expresión que inspiró el título de este reportaje es una oración propia del argot periodístico peruano. Su explicación es muy sencilla. En su libro "Argot Limeño o Jerga Criolla del Perú", Bendezú señala que el término "bacán" tiene varias significados, entre estos: bueno, excelente. En tanto que "nota" equivale a decir, en buen peruano, "tipear una nota" (escribir a máquina un artículo periodístico: de "to type", escribir). Es una frase coloquial que solía utilizarse en la época en que todavía reinaban las entrañables máquinas de escribir en las redacciones. 
"Pa' 1 gato".

Frase interjectiva y bien castiza ésta, que suele emplearse en varios países latinoamericanos, sobre todo en Perú y Chile. Así decimos "esto está pa'l gato" cuando queremos expresar resignada decepción ante algo de lo que esperábamos más, o cuando nos persigue la mala suerte, o cuando ya no hay remedio, cuando todo sale mal. Así se dice, por ejemplo: "la economía de este país está pa'l gato". Aunque la verdad, ignoramos qué tienen que ver en esto los pobres mínimos, que lo único que saben decir es "miau" y nada más.

Jergas con la misma acepción acá y acullá

A pata: a pié (Costa Rica, España, Chile, México, Perú)

Aventado: atrevido, osado (México, Perú)

Hacerse bolas: confundirse (México, Costa Rica, Colombia, Perú)

Chamba: trabajo (Colombia, México, Perú, Venezuela)

Chela: cerveza (Perú, México, Chile. También es birra en Puerto Rico, España, Venezuela)

Dar lata: molestar, fastidiar (Chile, México, España)

Gil: tonto, imbécil (Uruguay, Perú, Argentina, Chile)

Llama: dinero (Perú, México y otros países del hemisferio) 
Mocoso: despectivo de niño (En España y varios países americanos)

Por si las moscas: por si acaso (En casi todos los países hispanos)

Puto: hombre afeminado, homosexual (Venezuela, México, Argentina)

Rabo verde o viejo verde: hombre maduro que anda tras las jovencitas (Costa Rica, Perú, México, España y otros)

Taita: el papá, Dios (Perú, Colombia, Bolivia)

$\mathrm{Ni}$ fu ni fa, nuestro ni chicha ni limonada: algo que nos es indiferente (España, México, Argentina, Chile, Perú, Puerto Rico)

Trompearse: liarse a golpes (en casi todos los países hispanos)

Fuentes: Diccionario de la Real Academia Española / Portal "Jergas de habla Hispana"3

\section{5. ¿Química lingüística?}

Si le hacemos caso al poeta Juan de Arona ${ }^{4}$ (Nota 1), en el Perú, la lengua que trajeron los españoles en el siglo XVI habría sufrido una especie de transformación que sólo se entendería si aceptamos la existencia de una especie de "química" o transmutación que habría provocado un cambio radical del español, en el contacto de nuestro idioma con otras fablas o dialectos propios de tierras andinas, primero, y con

\footnotetext{
${ }^{3}$ Portal Jergas de Habla Hispana. http:/ / www.jergasdehablahispana.org/index.htm (04/04/04)

4 "Biblioteca Peruana". Promoción Editorial Inca SA (PEISA) Lima, 1974.
} 
otras lenguas no hispanas después. El poeta Juan de Arona, en su "Diccionario de Peruanismos"5 nos explica que lo sucedido con el español en nuestro país fue mucho más que la traducción de usos y modismos comunes del habla peninsular en otras acepciones que se acomodaron al modo de ser de la población peruana. Durante los últimos años de la Conquista y los primeros de la Colonia, se produjo, pues, un "mestizaje" de la lengua castiza, que no renunció a las voces de la tierra que la acogió, que las asimiló, que las adoptó como suyas, que las sometió a esa suerte de "química" o "alquimia", un "matraz" donde se ha de producir ese proceso de "ebullición jergal", que terminó dándole personalidad propia a nuestro decir popular. De hecho, son dos mundos que se oponen pero a la vez no se rechazan, como lamentablemente sucedió con el aspecto ideológico, religioso o político; dos mundos que, a fuerza de la palabra dicha y entredicha de mil maneras, encontraron sus senderos para complementarse, y aceptarse el uno al otro.

"Cuando ambos mundos se entienden a maravilla, aunque sólo sea en jerga -nos dice Juan de Arona en las "Observaciones Generales" de su diccionario -; cuando el disperso caudal de miles de voces esté registrado y unificado; otros "à quí de droit", se encargarán de fijar, limpiar, de dar esplendor. De lo que hoy es montonera, podría salir ejército regular de esos "peregrinos vocablos» de que hablaba el erudito Guzmán, ahora trescientos años, en la cita que dejamos estampada al frente de esta obra.

\footnotetext{
5 "Biblioteca Peruana". Promoción Editorial Inca SA (PEISA) Lima, 1974.
} 

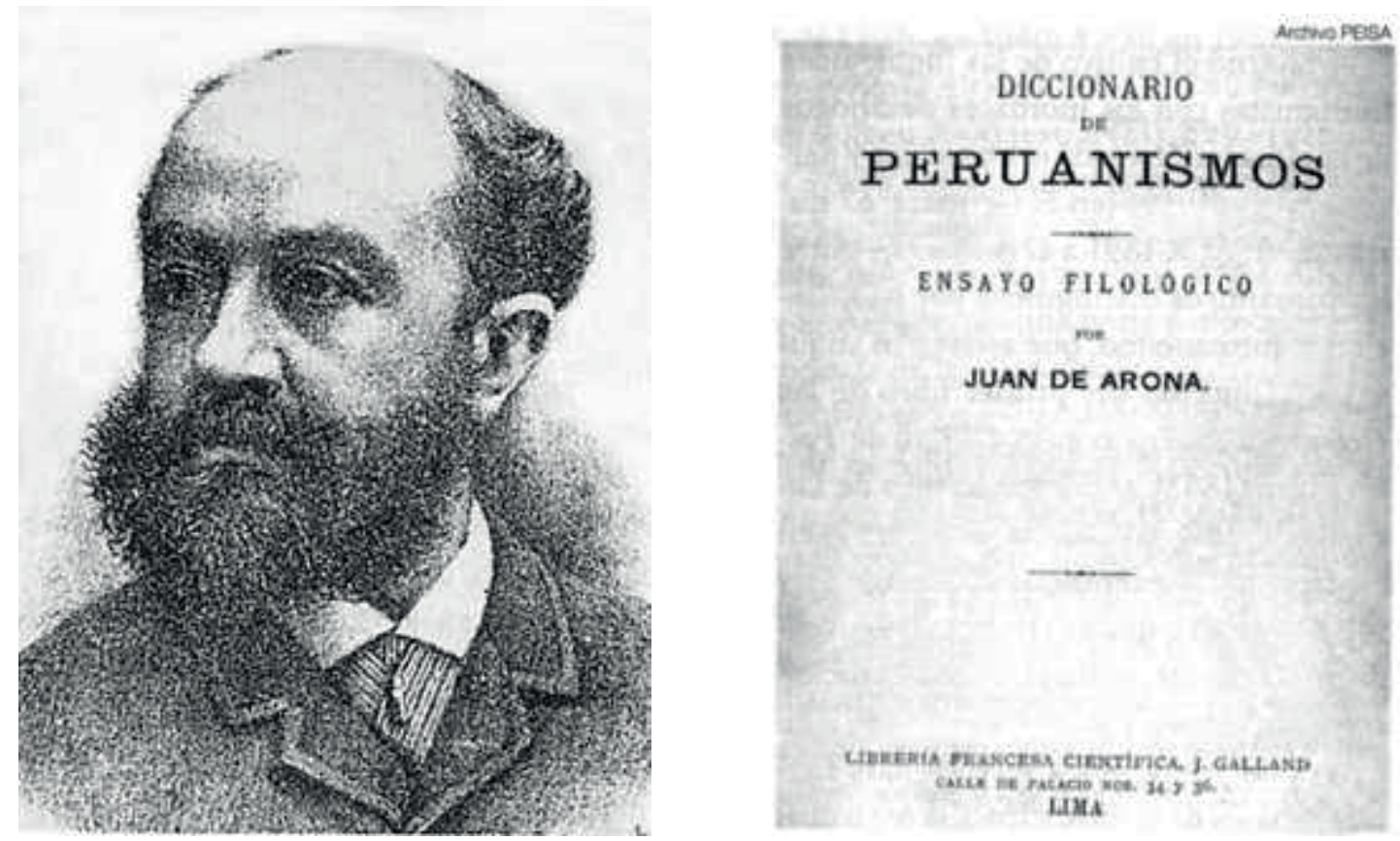

Figura 4 y Figura 5. El autor y su obra. Retrato de época de Pedro Paz Soldán (Juan de Arona), y la Portada de la primera edición de su "Diccionario de Peruanismos" (1884). Imágenes del "Diccionario Ilustrado Del Perú" de Tauro del Pino.

Verbos y proposiciones - En muchísimas locaciones cambiamos el verbo que traen, por otros, que si bien equivalente, no es el que consigna el Diccionario. «Llenar el expediente» decimos, por cubrir; «mandar a paseo o a rodar», por echar; "poner el cerrojo, la llave», por correr el primero y echar la segunda. «Caer a la calle» (la vista de alguna ventana) por dar o mirar; «todo queda en casa» por todo cae, \&."

"Esa misma tendencia, democrática, para decirlo de una vez, es la que nos lleva de una manera sorprendente a preferir siempre la palabra vulgar a la culta, sea que la equivalga en todas sus partes, en cuyos casos no revelamos sino nuestro mal gusto, sea que no la corresponda exactamente, y entonces cometemos una doble falta. 
Allí van copiosos ejemplos.

Mucho más decimos pescado que pez, candela que fuego, colorado que rojo, plata por dinero, pila por fuente, barriga que vientre, baraja que naipe, pelo que cabello, cáscara que corteza, flojera que pereza, cachete que carrillo o mejilla, palo que madera, migajón que miga, pellejo que piel, tierra que polvo, animal que bicho o sabandija, amarrar que atar, moverse que menearse, corazonada que presentimiento, pleito que riña, piedra que guijarro, china, peladilla, \&., que no conocemos; patada que coz, patear que cocear, pelear que reñir, poyo que alféizar, tabla que anaquel, anda vete por vete, que jamás usamos, prefiriendo lárgate; chicote, chicotazo, chicotillo y chicotear, \&., por látigo y sus derivados; rienda por brida, afrecho por salvado, arenillero por salvadera, echar pata por echarle la pierna encima a alguien (aventajarle), \&." 


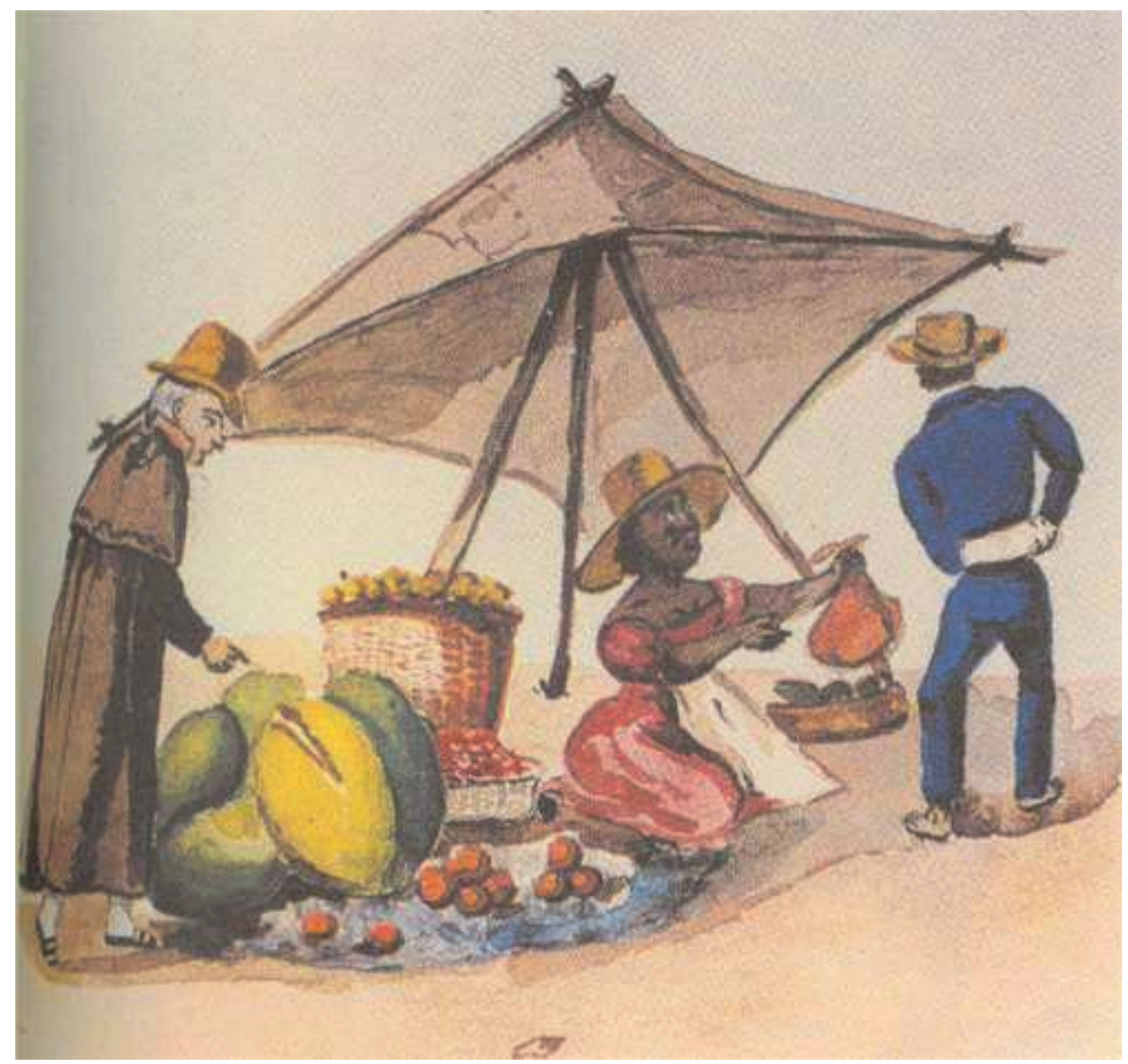

Figura 6. "Vendedora de frutas". Un retazo de la Lima que conoció Juan de Arona. Acuarela del Pintor mulato Pancho Fierro (1807 - 1879). Ilustración tomada del portal Amerique Latine.com (Francia).

Acercándonos más al presente, Guillermo Bendezú⿴囗十 nos aclara que la transformación del español en jerga no deforma el habla culta de la lengua de Cervantes, cuando escribe:

"Nuestro argot criollo y neologizante, es un habla marginal en el seno de la lengua común, empleada mayormente por gente de baja cultura -aunque nosotros consideramos que no necesariamente sólo este tipo de gente lo utiliza -; es una

${ }^{6}$ Mencionado por Bendezú en "Argot Limeño o Jerga Criolla del Perú". Editora e Importadora Lima. Lima, 1977. 
deformación, a posteriori, del idioma oficial, debido a matizaciones expresivas y reelaboradas en el diálogo cotidiano. El argot criollo suple, entonces, a medios expresivos de tendencia retórica, propia del lenguaje castizo; utiliza como en la lengua figurada una serie de recursos imaginativos y formales: metáforas, símiles, sinécdoques, metátesis, apócopes, homonimias, etc."

De otro lado, no es que el argot se proponga deformar el habla culta, no; al contrario, plenamente convencidos estamos de su aporte estilístico a las obras literarias de orden narrativo, exigiendo a la lingüística diacrónica el estudio de trastornos morfosemánticos en numerosísimas voces y formulando, a su vez, métodos de solución pertinente. El lenguaje argótico es tan funcional y directo como lo es el convencionalmente normativo: su habilidad informativa resulta más que precisa: "si no garpas la arruga, el vecino te abollará sin asco", se traducirá como: "Si no pagas la deuda, el vecino te golpeará sin miramientos."

Bendezú no sólo menciona la importancia que tiene el argot criollo dentro del desarrollo de la lengua castiza peruana, sino que hace hincapié en la necesidad de renovar las voces usuales por su escasa funcionalidad en un mundo globalizado que adapta nuevos términos cotidianos. Para este autor, la influencia argótica está aportando nuevas voces, palabras y significados, términos que la lengua oficial no es capaz de crear debido a sus normas estrictas y monolíticas, incapaces de innovar su propio léxico; y hay palabras de reciente cuño que han pasado a ocupar el lugar de otras del llamado lenguaje "culto", y también voces que están variando el mismísimo argot criollo.

"El fenómeno del cambio semántico -señala el autor - en todo sistema lingüístico, y concretamente en el nuestro, es de origen popular, no académico -no en vano podemos decir que, por más oficial que sea una lengua, ésta no es propiedad de un grupo de académicos; es del pueblo y el pueblo es quien la habla...-. Nuestra 
Real Academia propugna la pureza, propiedad y corrección de las palabras con demasiada rigidez. Ella se convierte en celosa guardiana y fiscalizadora exigente de los principios y normas que deben regir la vida y el desenvolvimiento idiomáticos. A nuestros usuarios corresponde, sin desmerecer el habla culta, hallar una originalidad expresiva que emerja del propio espíritu creador."

Las voces de nuestro argot, por tanto, se desenvuelven sin las cortapisas normativas que aprisionan las formas del "español oficial". Expresivas por antonomasia, estas voces corresponden, en un principio, al habla de las clases más humildes de ese gran conglomerado urbano que es Lima, una capital que recién está tomando conciencia de lo que es la descentralización, cuya población, 8 millones de habitantes, ya está dejando de pensar que el Perú es Lima y Lima es el Perú, y por ende, empiezan a mirar al terruño de donde procede el $90 \%$ de su población. Y corresponden también al habla de las clases medias, de los jóvenes, de los escolares, de los profesionales, de los empresarios, de las amas de casa. Y no cabe duda que ha sido en esta vieja Lima donde nació esta "vox populi", sin desmerecer la que creció en torno a cada pueblo y ciudad del territorio peruano.

\subsection{La replana criolla, una subcultura del argot}

Tal vez una de las variantes más sorprendentes del argot criollo es ese que se ha desarrollado en la marginalidad de las marginalidades. De por sí, no es un argot propiamente dicho. Recibe el nombre de "replana", es decir, la jerga delincuencial, la misma que configura un estatus muy particular que no podemos dejar de observar. Se trata, pues, del lenguaje especial del hampa, el mismo que se caracteriza por los recursos metafóricos que emplea, y la constante y variopinta dinámica funcional que la hace tan versátil. Su influencia ha hecho que voces y definiciones hamponescas circulen incluso en el argot común, con palabras y frases como: "chito", "as con el 
oro", "dar vuelta", "hacer el avión", "tanga", "maletear", "golpe", "charanga", "locatell", etc.

Con el paso del tiempo, la replana ha ido evolucionando y mezclándose con el lenguaje popular de todos los días -circunstancia que, ciertamente, ha confundido a más de uno-, invadiendo su vocabulario, donde puede encontrar un buen punto de apoyo para futuras expresiones, recreaciones y eventuales trasgresiones de la justicia y el orden público. Pero cabe advertir que no todos los que hablan con términos influenciados por la replana son, necesariamente, delincuentes, como se verá en la cita de abajo.

"Algunas de las voces (ladrones, tahures) -explica el lingüista español Manuel $\mathrm{Seco}^{7}$ - han alcanzado cierta extensión en el uso popular, perdiendo al mismo tiempo su adherencia al mundo delincuente donde nacieron. Otras aparecen usadas alternativamente por delincuentes y por honrados hombres de pueblo. Otras, por último, figuran solamente en boca de sus legítimos usuarios, funcionando precisamente como marcas caracterizadoras de los mismos."

El argot criminal, que comenzó como una especie de lenguaje secreto hablado por círculos muy cerrados, terminó en la boca, ya no de sus inventores, sino de personas extrañas a este sórdido mundo. Estas personas tienen acceso a la replana gracias a que su actividad desarrollada (oficio o profesión) está vinculada a la problemática delincuencial -pedagogos, asistentes sociales, periodistas, abogados, psicólogos, médicos, policías, etc. - - El común de las gentes o profanos propiamente dicho, no entenderán el significado de las siguientes palabras:

a) A Esteban lo enfriaremos de turno por maloso.

${ }^{7}$ Arniches y el habla de Madrid. Editorial Alfaguara, Madrid, 1970. Pág. 136. 
b) Aquel chochamu debe jalar pa' la charanga verdolaga.

c) ¡Merfis los kinkones de susioma chito!

d) Buen turno, ganchurime; buen claro, feligrés.

Los significados usuales para el hampa criolla de estos términos son, respectivamente:

éste/ victimaremos/ noche/ muchacho/ conducir/ camioneta/ verde/ aparentes, bonitos/ zapatos grandes y toscos/ usted/ amigo/ buenas noches/ compañero, amigo/ buenos días/ señor/

\section{Los recursos ingeniosos del argot criollo}

Todas las formulaciones en el habla popular -sean de vieja data o de reciente cuñohan contribuido a enriquecer la lengua jergal, compendiando la viva imaginación de cada grupo social. Como ya vimos, entre éstos se tienen: la metáfora, el símil, la metonimia, la sinécdoque, etc., considerados como tropos en la lengua literaria.

$\underline{\text { Recursos de la jerga criolla con sus significados etimológicos y ejemplos. }}$

Tropo: Consiste en dar vuelta un objeto, cambiar el significado de algo.

Ej.: "El tigre es un animal feroz". "Demetrio es un tigre".

Metáfora: Consiste en trasladar el significado de una palabra.

Ej.: "El Sol es un globo de fuego y la Luna un disco Plateado".

Ej.: "El globo de fuego surcaba el espacio junto al disco plateado". 
Símil: Se diferencia de la metáfora en que es una comparación explícita (expresa).

Ej. Símil: "Como un globo plateado se pierde en la inmensidad del firmamento."

Ej. Símil de metáfora: "El globo plateado se pierde en la inmensidad del firmamento".

Animismo: Es un tipo especial de metáfora que consiste atribuir vida, animas vivendi, espíritu (alma, vida humanizada) a seres inanimados (cosas) o animales propiamente tales.

Ejs.: a) "Se duerme en la yerba el sol."

b) "Los gorriones discuten acaloradamente sin motivo".

c) "La yerba bondadosa del campo agreste invita al descanso".

d) "El oro es un metal ensoberbecido por las pasiones humanas".

La Personificación (humanizar o prosopopeyar): Consiste en atribuir cualidades humanas a seres inanimados, ya sean plantas, cosas, fenómenos, animales, etc.

Ej. "El tigre se molestó con él".

Metonimia: Es el tropo que responde a la fórmula lógica Parte por parte. Consiste en designar una cosa con el nombre de otra que está con ella en una de las siguientes relaciones:

La causa por el efecto: "Regálame un cáncer pa' contrarrestar el frío" (cigarrillo).

El objeto por la materia: "Son muy costosos los cueros de charol" (monederos).

El contenido por el continente:

Ejs.: a) "Se cargaron la lata de sardinas" (dinero, caudales, joyas) / bóveda, cajafuerte/

b) "Beberemos algunas botánicas heladas" (licor, cerveza) /botellas, recipientes/ 
El lugar por el producto: "Nos serviremos un pisconti para matar el frío" (Puerto de Pisco) /aguardiente, cañazo/

La significación por el símbolo o cosa:

Ejs.: a) "Laureano traicionó a su bandera" (patria, nación).

b) "Por Betty dejará la sotana Rafael" (vida monacal).

Lo concreto por lo abstracto:

Ejs.: a) "Barrió la vigilancia escurridizo ladrón" (policía, guardián).

b) "Fernando es un amor pa' todos sus hijos" (padre ejemplar).

Sinécdoque: Tropo que responde al esquema lógico La parte por el todo, o viceversa. Se produce al emplear una palabra por otra, estando los conceptos respectivos en la relación formal de:

Género a especie o viceversa: "Trasladarán a los cuadrúpedos enfermos" (solípedos, caballos).

Parte a todo o viceversa: "Todo es muy amigo de las faldas" (mujeres).

Singular a plural o viceversa: "ique tales ponjas pa' progresar" (los japoneses).

Onomatopeya: Es un recurso mixto, entre formal e ingenioso, cuya característica es reproducir fonéticamente los sonidos y ruidos de la naturaleza, así como las interjecciones vehementes.

Recuérdese cómo la interjección de dolor AY se formaliza en un verbo frecuentativo Ayayear con sentido de "gritar, fomentar bulla, escándalo, dar voces estentóreas, reclamar algo de viva voz". Ayayero será el reclamoso, gritón, protestón. En las organizaciones políticas se considera al ayayero como la persona encargada de organizar y preparar las grandes concentraciones políticas o mitines populares, condicionando sus servicios a la compensación pecuniaria del candidato en caso de éxito electoral, o a los puestos de favor en la administración pública. 
Otro tanto ocurre con Pichi (orina), para ser más realista y familiares, que reprodujo el efecto sonoro, poco perceptible de Piss, Pissss (en el acto de mear el nene), constituyendo una referencia apelativa, al momento en que la madre emite o reproduce la voz onomatopéyica insinuando a su retoño decida "hacer agua", "regar el jardín", orine, simplemente. Luego en vez de "ha hecho pish" se dice "ha hecho pichi", "pichulón".

Otro tanto ocurre con la formalización de Chis, como expresión espontánea de "chitón": (¡cállate!), "¡puchica!".

En el caso anterior de Pichi, la hemos derivado en "pichica", "pichín", "pichón", "pichulón".

Por tanto: Onomatopeya es la formulación de una palabra cuyo sonido remeda o es imitativo de la cosa significada, tal como en "miau", "zis", "zas", "rataplán", "pis", "gluglú", "pum", "pam", "tití", etc. (...)

Finalmente, la materialización sonora se formaliza en la literatura y sirve de apoyo estilístico, tal por ejemplo, con los ruidos de la naturaleza que combinados rítmicamente producen un efecto armónico, melodioso, dando lugar a la figura literaria llamada Paranomasia, que es la armónica combinación de sonidos semejantes cadena hablada, así como en el texto poético.

Son ejemplos:

a) Ronco trueno que en horrísono fragor revienta. (insistencia de R)

b) En el silencio sólo se escuchaba el zumbido de la abeja. (S)

c) Afuera soplaba el viento anunciando tempestad. (Insistencia de S)

El contexto (c) corresponde a la última parte de la novela social "El Tungsteno" de César Vallejo, el mejor poeta de habla hispana. 
Mención aparte: Neologismo: Se llama así a la nueva acepción o sentido convencional que se otorga a una palabra o frase; es decir, la estructura formal del vocablo se mantiene intacta, pero cambia de significado.

Ejemplifiquemos:

Bobo. Reloj u.t.c. Corazón.

Bola. Rumor o noticia falsa, sin trascendencia. Sin Bolada.

Cachimbo. El postulante que ingresa a primer año de universidad.

Legal. Estupendo, extraordinario. u.t.c. Bueno de calidad.

Mancha. Conjunto de personas amigas. u.t.c. Grupo, gente.

Los neologismos significacionales son mucho más numerosos que los formales y se multiplican incesantemente en la lengua coloquial. El uso parlante y la lengua literaria serán los que a posteriori los sancionen como legítimos y funcionales. Fuente: "Argot Limeño o Jerga Criolla del Perú"8.

\section{7. ¿Sabía Usted que...?}

...en Estados Unidos ya no saben qué hacer. Los gringos quieren imponer a toda costa su inglés, y hasta botan a cuanto hispano sin papeles se les ponga en medio; sin embargo, las estadísticas indican que en el 2025, la mitad de la población estadounidense estará hablando la lengua del Quijote y Sancho Panza, muy a pesar de ellos.

.. El "Diccionario de la Real Academia Española", en su última y 22 ${ }^{a}$ Edición (2001), incorporó 12.122 artículos que tienen una o más acepciones correspondientes a estas zonas (La edición anterior contenía 6.141). 18.749 acepciones tienen una o más

\footnotetext{
${ }^{8}$ Op. Cit.
} 
mascas correspondientes América y Filipinas: (En la edición anterior había 8.120). Hay 28.171 marcas correspondientes a las zonas aludidas. (La edición anterior contenía 12.494) .

...en el Perú la palabra "quemar" significa "contraer una enfermedad venérea y, por extensión, recibir una sorpresa desagradable, una decepción. Alfredo se levantó a una en un bar y "se quemó". / Rita compró dólares en la calle y se quemó porque eran todos falsos. Otra acepción es perder la reputación, usada para políticos, artistas u otro tipo de personaje público. Esa actriz ya debe cambiar el tipo de papeles que desempeña si no quiere "quemarse". Asimismo, en este país y en Argentina, es sinónimo, también, disparar un arma de fuego... "te voy a quemar si no me das tu cartera"10.

\section{Para saber más}

(Nota: A la derecha de los hipervínculos se ha insertado la fecha de última apertura de la página Web citada)

Jergas, modismos y lisuras en la televisión peruana de los años 60 y 70.

http://www.arkivperu.com/cronica2.htm (04/04/04)

Diccionario Popular Venezolano.

http://www.nacionesunidas.com/diccionarios/venezuela.htm (04/04/04)

El Español de Perú.

http://www.geocities.com/esp_peru/ (04/04/04)

\footnotetext{
9 "Real Academia Española - Diccionario de la Lengua Española". http:// buscon.rae.es/diccionario/drae.htm (04/04/04)

${ }^{10}$ Curiosidades jergales. http://www.jergasdehablahispana.org/curios.htm (04/04/04)
} 
Escribir en peruano

http://sisbib.unmsm.edu.pe/BibVirtualData/Libros/Literatura/imagen_inclusion_ andina/cap3.pdf (04/04/04)

Jerga de España I y ss.

http:/ / www.jergasdehablahispana.org/ espana.htm (04/04/04)

Jerga de México I y ss.

http:/ / www.jergasdehablahispana.org/mexico.htm (04/04/04)

Jerga del Perú.

http:/ / www.jergasdehablahispana.org/ peru.htm (04/04/04)

Jerga del Español en EEUU.

http:/ / www.jergasdehablahispana.org/ eeuu.htm (04/04/04)

La chicha, cultura urbana que emerge.

http:/ / www.er.uqam.ca/nobel/gricis/actes/panam/Gargurev.pdf (04/04/04)

Diccionario de la Lengua española.

http:/ / buscon.rae.es/diccionario/ cabecera.htm (04/04/04)

\section{Notas}

Nota 1. Su nombre completo era Pedro Paz Soldán y Unánue, aunque firmaba como Juan de Arona y así fue conocido por todo el mundo. Se le considera un poeta perteneciente a la generación romántica, pero un hombre de gran cultura humanística, políglota -hablaba latín, inglés, alemán, francés, italiano-, fue profesor universitario de literaturas antiguas -griego y romano-, y como lingüista 
dominador, como pocos, del castellano. Su enorme bagaje cultural incluía otras disciplinas -además de poeta, era periodista, comediógrafo, escritor costumbrista y de viajes, crítico, diplomático...-. Sin embargo, para su infortunio, vivió en una época que no supo valorar su talento creador. Aún así nos dejó innumerables obras, entre éstas su "Diccionario de Peruanismos", texto obligado ahora para todo estudiante o investigador de nuestra lengua popular.

Nota 2. La voz "Gringo", como se vio, proviene de "green go home" (verdes, váyanse a casa), se cuenta que acuñada a mediados del siglo XIX durante la guerra en la cual Estados Unidos invadió el norte de México para arrebatarle los territorios de Texas, Arizona y Nuevo México. De esta forma, los mexicanos exigían a los "verdes", por el color del uniforme de los soldados estadounidenses, que se fueran a sus casas.

\section{Procedencia de las imágenes}

(Nota: A la derecha de los hipervínculos se ha insertado la fecha de última apertura de la página Web citada)

1. "Amigos conversando". Caricatura de Oswaldo Mejía. Suplemento Dominical del Diario OJO, Lima (1990).

2. "No soy un argollero". Caricatura de Jorge Monterrey. Suplemento Dominical del Diario OJO, Lima (1998).

3. "Hay que tener cuidado con los piropos. En Colombia jamás diga a una chica que es un "avión"... Foto archivo OJO (1998).

4. Retrato de época de Pedro Paz Soldán, (Juan de Arona). "Enciclopedia Ilustrada del Perú" de Tauro del Pino. PEISA, Lima, 2001. 
5. Portada de la primera edición del "Diccionario de Peruanismos", Juan de Arona. "Enciclopedia Ilustrada del Perú" de Tauro del Pino. PEISA, Lima, 2001.

6. "Vendedora de frutas". Acuarela costumbrista del pintor Pancho Fierro. http:// amerique-latine.com/ala/fr/esclavage.html (05/03/04)

\section{Recortes}

\subsection{La Divina Jeringa}

Artículo que parodia la 22 $2^{\mathrm{a}}$ edición del "Diccionario de la Real Academia", publicado en la edición 1654 de la revista Caretas. Lima, 25 de enero de 2001.

El humorista Fedor Larco publica diccionario de jerga siguiendo pautas de la Real Academia de la Lengua.
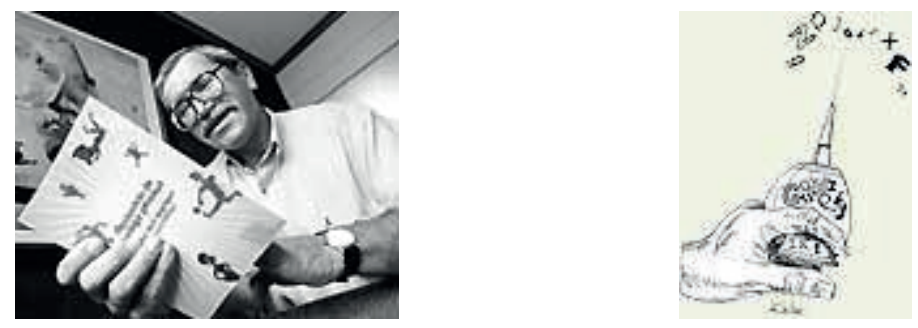

"Ay carretita, hace 50 años con Mario Cavagnaro, convertimos la jerga en replana, o sea la adaptamos para la clase media". "Yo la quería patita" (1952), valse de callejón, fue el primer trino replanero. Entonces, Jorge Pérez se sentía un Don Nadie con cien homónimos en el padrón electoral y empezó a carretear a todo el mundo hasta que de rebote fue reconocido como el único Carreta. Así es la jeringa, un proceso seminal, un rebautizar las cosas con la gracia popular de los chaplines. 
En 1958, en repique de replana, Perez lanzó con Augusto Polo Campos "Vamos a un Jaramillo", un valsario que baraja onomatopeyas, apellidos de futbolistas, marcas y referencias populares: Vamos a un Jaramillo/o sino donde santana/donde hay palos trinadores/feligresas a granel/cuando estemos en la mesa/tú te me vas de Miranda/a ver cómo anda Patiño/en la Compañía Ollanta/mientras yo estoy con Cervantes/con Picasso y Chichizola...

Cervantes se convirtió en la chela cantada por poetas de los setentas como Lucho Hernández, rubia que pone en fa, o malta que pone oso (la publicidad engordó al lenguaje para explotarlo mejor) y se tomó al polo o al tiempo, en margaritos, en basadres o a pico. La gila más buenamoza del callejón se hizo maroca rumbera, luego ruca salsera, y, más recientemente jugadora pues, aunque la postmodernidad le dio más recursos, sigue jugando lo mismo de siempre, el choro. Y le salió competencia de brócolis, coliflowers, buses, chimbombos y brinchis. El arriola le entra a todo y si no, cinco dedos de furia, ahorcar payaso, caput.

¿Acaso no hay jeringa para designar a los machos sexistas? No, porque el Perú es aún una sociedad patriarcal. Lo último que perderá el macho es el dominio del lenguaje. La jeringa empieza a las patadas, en el fulbito, y de ahí se cocina en el fulvaso hasta que la prensa chicha la imprime en primera plana.

Sin embargo, Fedor Larco, autor del Diccionario de jeringa peruana publicado por la agencia de publicidad Causa nos recuerda la primera teoría explicativa de todos los argots: que son los grupos sociales con necesidad de diferenciarse los que requieren un lenguaje que no sea inmediatamente reconocible. Los jóvenes son los primeros generadores de jerga, para no hablar de grupos específicos como delincuentes, gays, rockeros, tablistas, etc. El diccionario de Larco surgió precisamente de focus groups juveniles en el departamento de investigación de Causa. 
La jeringa redimensiona el mundo para quien la aplica. El gringo esta africanazo, estoy resinaza; me meto al marcelo; dice un kemoly playero a otro. Aguanta. La toso de una vez, dice su causa. He triqueado en mate, huon. Más tarde, dos malogrados en un baño barranquino: Oe cuñau, ¿tienes un ketinvidal? Quiero un ñecs. O el pata a su hembrita: vamos al telo pero antes pasamos por el jeroca. Esto no es floro, es comunicación y todo indica que en el futuro va a ampliar sus alcances, in english y al vesre. Saquen su línea. (Fernando Vivas).

\section{Glosario:}

Africano,azo. Dícese del gringo cuando esta bravazo.

Ahorcar payaso. Masturbarse, echarse unos cinco.

*Arriola. Dícese del que padece arrechura.

Choro. Organo sexual femenino.

*Floro. Rollo retórico.

*Fulvaso. Tranca después del fulbito.

*Gringo. El sol.

Jeroca. Cajero para tarjetas de débito.

Jugar el choro. Conceder la mujer favores sexuales al varón.

Kemoly. Dícese del que quemó neuronas. No es un pastrulo pues ha consumido fundamentalmente macoña.

*Ketín. Un quete.

Marcelo. Mar.

*ñecs. Un pellizco de coca.

Resina,aza. Cochino, sucio, pringoso.

*Sacar línea. Entender el cómputo ajeno.

*Telo. Hotel u hostal para tirar.

Toser. Decir lo que se tiene aguantado.

Triquear. Repetir un curso por tercera vez. 
Jerga - Identidad - Criollo - Hablantes- Identidad - Criollo - Hablantes

*Vesre. Revés, voltear palabras.

*Estas palabras están definidas en el "Diccionario de jeringa peruana" de Fedor Larco. Lo demás ha sido recopilado en casa. 